\title{
NOTE
}

\section{Effects of extracellular products from phytoplankton on the excystment of tintinnids from marine sediments}

\author{
Takashi Kamiyama
}

Nansei National Fisheries Research Institute, Ohno, Saeki, Hiroshima, 739-04, Japan

\begin{abstract}
The effects of extracellular products from phytoplankton on the excystment of tintinnids from marine sediments were examined by incubating sediment samples in filtered seawater to which was added filtrates from 4 phytoplankton cultures. The incidence of excystment of 2 species of tintinnid, Eutintinnus tubulosus and Helicostomella longa, was much greater in the presence of filtrates from the phytoplankton cultures than in either filtered seawater only or in filtered seawater containing the phytoplankton culture medium. The promotion of excystment by the extracellular products from phytoplankton is considered to be advantageous for the development of planktonic populations of these tintinnids.
\end{abstract}

KEY WORDS: Tintinnids - Ciliates - Excystment - Marine sediments Phytoplankton

In coastal waters tintinnids can occur suddenly in great abundance (Kršinić 1987, Paranjape 1987, Graziano 1989). The phenomenon depends on the ability of tintinnids to form cysts and thereby survive unfavorable conditions (Reid \& John 1978, Paranjape 1980). Thus, excystment plays an important role in the formation of initial planktonic populations of tintinnids. Kamiyama \& Aizawa (1992) reported that temperature and light affect tintinnid excystment and suggested that other environmental factors may also influence tintinnid excystment. To the author's knowledge, no studies on the influence of these other environmental factors on tintinnid excystment have been published to date. In this paper, the effects of extracellular products from phytoplankton on the excystment of tintinnids from marine sediments are reported.

Materials and methods. Sediment samples were collected in winter at 2 coastal sites $\left(34^{\circ} 16^{\prime} \mathrm{N}, 132^{\circ} 16^{\prime} \mathrm{E}\right.$ and $34^{\circ} 20^{\prime} \mathrm{N}, 132^{\circ} 23^{\prime} \mathrm{E}$ ) in Hiroshima Bay, within the Seto Inland Sea of Japan, using a gravity core sampler. The sites were $11 \mathrm{~m}$ and $15 \mathrm{~m}$ in depth, respectively. The upper $3 \mathrm{~cm}$ of sediment, which was composed almost entirely of silt, was stored for several months under cold $\left(5^{\circ} \mathrm{C}\right)$ and dark conditions. Two experiments were then conducted; the sediment sample collected from the first site was used for the first experiment and that from the second site for the second experiment. The sediment samples were sonicated and fractionated with filtered seawater (Whatman GF/C) from the western Hiroshima Bay collected on a different day for each experiment. For each experiment a sediment suspension prepared with $0.16 \mathrm{~g}$ wet weight $\mathrm{ml}^{-1}$ of the 20 to $125 \mu \mathrm{m}$ size fraction was used.

In the first experiment, the effects of filtrates from phytoplankton cultures on tintinnid excystment were examined. Four kinds of filtrates were prepared by filtering cultures of Heterocapsa triquetra $(2.03 \times$ $10^{4}$ cells ml$\left.{ }^{-1}\right)$, Heterosigma akashiwo $\left(1.25 \times 10^{5}\right.$ cells $\left.\mathrm{ml}^{-1}\right)$, Pavlova lutheri $\left(4.22 \times 10^{6}\right.$ cells $\left.\mathrm{ml}^{-1}\right)$ and Chaetoceros sp. $\left(3.24 \times 10^{5}\right.$ cells $\left.\mathrm{ml}^{-1}\right)$ through Whatman GF/C filters under low vacuum pressure $(<100 \mathrm{~mm} \mathrm{Hg})$ and were stored frozen. These filtrates were used for this experiment immediately after thawing and filtration through a Millex-GS $0.22 \mu \mathrm{m}$ filter (Millipore). Fifty ml of the sediment suspension was dispensed into fifteen $200 \mathrm{ml}$ flasks. Three $\mathrm{ml}$ of each filtrate was added to each of 3 flasks. To the remaining 3 flasks, $3 \mathrm{ml}$ of the glass-fiber filtered seawater was added immediately after filtration through a $0.22 \mu \mathrm{m}$ filter. All flasks were incubated at $20^{\circ} \mathrm{C}$ under 2000 lux on a $14 \mathrm{~h}$ light: $10 \mathrm{~h}$ dark cycle. Each day, most of the supernatant seawater in the flasks was collected, immediately fixed with Lugol's iodine, and any cells in it were concentrated by settling. Freshly filtered seawater $(50 \mathrm{ml})$ and the same culture filtrate $(3 \mathrm{ml})$ were added to each residual sediment sample. These treatments were repeated for $5 \mathrm{~d}$ (Kamiyama \& Aizawa 1990). The concentrated samples from the $5 \mathrm{~d}$ period were pooled for each treatment, and 


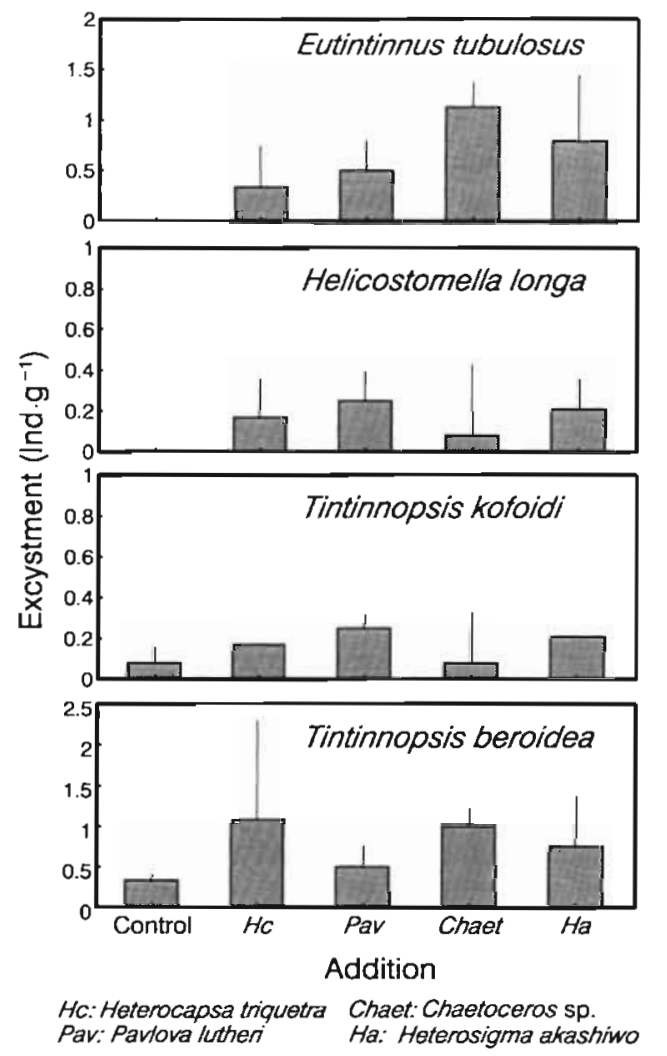

Fig. 1. Effects of filtrates from 4 phytoplankton cultures on tintinnid excystment. Control represents the results with the addition of filtered seawater only. Vertical lines indicate standard deviation of the mean $(n=3)$

then reconcentrated to $1 \mathrm{ml}$. Tintinnids were identified and counted for each sample using a phase-contrast microscope.

The second experiment was designed to examine whether the effects of the filtrates on tintinnid excystment were due to extracellular products from phytoplankton or to dissolved materials in the phytoplankton culture medium. Fifty milliliters of the sediment suspension was dispensed into 9 flasks. The filtrate from a culture of Pavlova Iutheri $\left(3.29 \times 10^{6}\right.$ cells $\left.\mathrm{ml}^{-1}\right)$. culture medium for phytoplankton (modified SWM-3; Itoh \& Imai 1987) and the filtered seawater were added to each of 3 flasks. The experiment was then conducted in the same manner as the first.

Results. In the first experiment, the incidence of tintinnid excystment was greater in all experimental treatments than in the control treatment that used only filtered seawater. Excystment of Eutintinnus tubulosus and Helicostomella longa occurred in all experimental treatments, but was not observed in the controls (Fig. 1). These results demonstrate that the filtrates from the phytoplankton cultures promoted the excystment of these tintinnid species. The filtrates from the phytoplankton cultures contained both extracellular products from the phytoplankton and dissolved materials that were in the culture medium.

In the second experiment, the incidence of excystment of Eutintinnus tubulosus was significantly greater in the presence of Pavlova lutheri filtrate than in the presence of filtered seawater only or the phytoplankton culture medium ( $p<0.05$; Fig. 2). A similar trend was found for excystment of Heliostomella longa, although the difference between that in the presence of $P$. lutheri filtrate and that in the other, treatments was not significant. This confirms the results of the first experiment and shows that it is the extracellular products from the phytoplankton that promote the excystment of $E$. tubulosus and $H$. longa.

Discussion. Since resting cysts of tintinnids are thick-walled and resistant to immersion in strong acids (Reid \& John 1978, Paranjape 1980), investigation of the stimulation of tintinnid excystment has focused on environmental factors such as temperature or light which can pass through the cyst wall (Paranjape 1980, Kamiyama \& Aizawa 1992). The evidence presented in this report demonstrates that dissolved materials, such as extracellular products from phytoplankton, can also stimulate tintinnid excystment. At this stage the characteristics of the dissolved materials and the mechanism by which these materials stimulate excystment are unknown. Further studies are necessary to elucidate the nature of these materials and to clarify this mechanism.

In this report, the excystment of tintinnids was caused by a change of conditions $\left(5^{\circ} \mathrm{C}\right.$ in darkness to $20^{\circ} \mathrm{C}$ under periodical light) with the addition of filtrate from phytoplankton cultures. These environmen-
Eutintinnus tubulosus

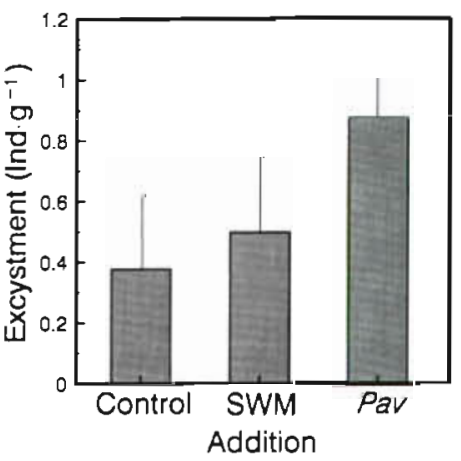

Helicostomella longa

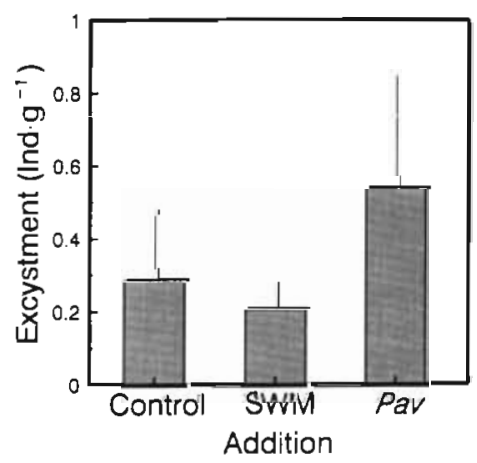

Fig. 2. Effects of culture medium (SWM = modified SWM-3) and filtrate from a culture of Pavlova lutheri (PAV) on the excystment of 2 species of tintinnids. Control represents the results with the addition of filtered seawater only. Vertical lines indicate standard deviation of the mean $(n=3)$ 
tal factors are probably important for excystment of tintinnids in marine sediments. Assuming the environmental conditions in this investigation were suitable for the excystment of tintinnids, the population size of total tintinnid cysts in the upper $3 \mathrm{~cm}$ of bottom sediment was estimated to be 2 to 3 individuals per $g$ wetweight sediment at these sampling stations. However, this population size may be underestimated, because the optimum environmental conditions for excystment, such as light irradiance or abundance of phytoplankton, were unknown. The optimum levels of environmental conditions for the excystment must be clarify for exact estimation of the population size of tintinnid cysts.

In the control treatments, no excystment of Eutintinnus tubulosus and Helicostomella longa was detected in the first experiment, whereas some excystment was detected in the second experiment. Perhaps there were more cysts of both species in the sediment sample used in the second experiment than in the first experiment. Also, since the seawater used in the 2 experiments was obtained on another day, the dissolved materials in the control treatments in the second experiment may have influenced tintinnid excystment more strongly than in the first experiment.

In this report, the extracellular products from phytoplankton are considered to have stimulated excystment of tintinnids directly. However, since extracellular products from phytoplankton consist of organic matter, there is a possibility that excystment of tintinnids was influenced by bacteria growth or appearance of small protists which may be stimulated by the extracellular products from phytoplankton. Unfortunately, abundance of bacteria and non-tintinnid protists were not measured. Interactions between excystment of tintinnids, appearance of non-tintinnid protists, bacteria growth, and extracellular products from phytoplankton may be interesting topics for further study.

High levels of extracellular products from phytoplankton are generally associated with high densities of phytoplankton in the sea, which means an abundance of food for tintinnids. Hence, the promotion of tintinnid excystment by extracellular products from phytoplankton would seem to be advantageous for the rapid development of their planktonic populations. Similarly, spawning of marine invertebrates was stim-

This note was presented by K. Furuya, Tsu, Japan ulated by extracellular products of phytoplankton and close contact with phytoplankton cells, suggesting that the spawning can occur under favorable conditions for larval growth and larval survival (Starr et al. 1990, 1991). In Hiroshima Bay, the 2 species of tintinnids, Eutintinnus tubulosus and Helicostomella longa, whose excystment has been shown to be promoted by extracellular products from phytoplankton, occur in abundance in the season when phytoplankton are abundant. The stimulation of excystment of these species by extracellular products from phytoplankton may be an important strategy for increasing their planktonic populations.

Acknowledgements. I am grateful to Drs T. Honjo and $K$. Tamai for their critical reading of the manuscript.

\section{LITERATURE CITED}

Graziano, C. (1989). On the ecology of tintinnids (Ciliophora: Oligotrichida) in the North Irish Sea. Estuar. coast. Shelf Sci. 29: $233-245$

Itoh, K., Imai, I. (1987). Rafido so (Raphidophyceae). In: Japan fisheries resource conservation association (ed.) A guide for studies of red tide organisms. Shuwa, Tokyo, p. 122-130 (in Japanese)

Kamiyama, T., Aizawa, Y (1990). Excystment of tintinnid ciliates from marine sediment. Bull. Plankton Soc. Japan 36: $137-139$

Kamiyama, T., Aizawa, Y. (1992). Effects of temperature and light on tintinnid excystment from marine sediments. Nippon Suisan Gakk. 58: 877-884 (in Japanese with English abstract)

Kršinić, F. (1987). On the ecology of tintinnines in the Bay of Mali Ston (eastern Adriatic). Estuar. coast. Shelf Sci. 24 $401-4.18$

Paranjape, M. A. (1980). Occurrence and significance of resting cysts in a hyaline tintinnid, Helicostomella subulata (Ehre.) Jørgensen. J. exp. mar. Biol. Ecol. 48: 23-33

Paranjape, M. A. (1987). The seasonal cycles and vertical distribution of tintinnines in Bedford Basin, Nova Scotia, Canada. Can. J. Zool. 65: 41-48

Reid, P. C., John, A. W. G. (1978). Tintinnid cysts. J. mar. biol. Ass. U.K. 58: 551-557

Starr, M., Himmelman, J. H., Therriault, J. C. (1990). Direct coupling of marine invertebrate spawning with phytoplankton blooms. Science 247: 1071-1074

Starr, M., Himmelman, J. H., Therriault, J. C. (1991). Coupling of nauplii release in barnacles with phytoplankton blooms: a parallel strategy to that of spawning in urchins and mussels. J. Plankton Res. 13: 561-571

Manuscript first received: September 16, 1993

Revised version accepted: December 7, 1993 